\title{
Gender and Ethical Issues Arising from the Implementation of the Services of Surrogate Motherhood
}

\author{
Inna G. Garanina ${ }^{1}$, Nail S. Moustakimov ${ }^{1}$, Tatiana A. Izbienova ${ }^{1} \&$ Tatiana F. Timofeyeva ${ }^{1}$ \\ ${ }^{1}$ Mari State University, Yoshkar-Ola, Russia \\ Correspondence: Inna G. Garanina, School of Law, Mari State University, Yoshkar-Ola, Republic of Mari El, \\ 424000, Russia. Tel: 7-836-242-3241. E-mail: ilneza@mail.ru
}

$\begin{array}{lcc}\text { Received: February 21, } 2015 & \text { Accepted: March 15, } 2015 \quad \text { Online Published: April 29, } 2015 \\ \text { doi:10.5539/res.v7n8p112 } & \text { URL: http://dx.doi.org/10.5539/res.v7n8p112 }\end{array}$

\begin{abstract}
The authors of this article consider the ratio of legal and social aspects of the regulation of surrogate motherhood in international human rights law. The article details disclosed ethical, moral and religious aspects of the institution of surrogate motherhood. The authors reveal and analyze different perspectives on the issues of the institute of surrogate motherhood from the perspective of the implementation of reproductive rights.
\end{abstract}

Keywords: surrogacy, reproductive choice, international law of human rights, right to reproductive choice, surrogate motherhood

\section{Introduction}

The central theme of the research of the legislation of different countries in terms of gender mainstreaming is to respect the principle of gender equality and non-discrimination on grounds of sex in the legal acts regulating the relations of citizens about the birth of children, forms of sexuality and government guarantees aimed at protecting the reproductive health of citizens.

Under international law of human rights, adopted by the international community, reproductive freedom and the citizen's right to health care, regardless of gender, ethnic or social origin, place of residence, are an integral and essential part of human rights (Kirillovih, 2012).

Standards, as reflected in international legal acts and documents adopted by UN conferences and conferences, other major international organizations, based on a thorough study of the processes of development of modern civilization. That is why the development of the principles of law and directions of social and economic policy of the public authorities should not only take into account the findings of the international community on the current state of society and its development prospects, but also to give those rules and conclusions priority. This approach is fixed and the current Constitution of the Russian Federation (Makeyeva, 2011).

Belonging to a particular floor includes a hierarchical element, according to which men are considered superior beings in relation to women, and, accordingly, tasks, functions and values that belong to men is higher in importance than those that relate to women. The problem here lies in the hierarchy floor rather than in women as such.

\section{Material and Methods}

Equality between women and men, as well as the rights of the human person, part of which it is, is a principle that must constantly defend, protect and promote (Samoylova, 2010).

Despite the progress made since the IV World Conference on Women, held in Beijing in 1995, discrimination against women persists in all regions and societies and systematic and egregious violations of women's human rights continue both at law and in practice.

Inequality of women is increasingly recognized as a human rights violation. Governments are more aggressively apply the Convention on the Elimination of All Forms of Discrimination against Women and the Beijing Platform for Action to ensure that civil, cultural, economic, political and social rights of women are respected. More and more countries apply the principles of equal opportunities and equal treatment of women and girls at all stages of their lives in accordance with the Convention on the Elimination of All Forms of Discrimination against Women. 


\section{Results}

Violence against women - is a crime, regardless of where it occurs: in the family, in a public place or in the conflict zone. Breakthrough in relation to this subject has been made in the course of litigation International war crimes tribunals for Rwanda and the former Yugoslavia, which recognized rape as a war crime, and its systematic application - a crime against humanity. Companies to prevent violence, many of which are aimed at increasing the level of consciousness of men and boys, are held within the framework of increasing efforts to change attitudes and traditions that are harmful to women and girls (Kozheourova, 2009).

Gender inequality can be seen in the legislation of the Russian Federation. Russian legislation the concept of "motherhood" is used by various branches of law.

1) For example, in family law "motherhood" and, accordingly, "fatherhood" are considered from the perspective of parental rights and responsibilities.

The origin of the child from the mother is established on the base of documents confirming the birth of her child in health care settings, and in the case of the birth of a child is a medical institution —on the base of medical documents, testimony and other evidence (Tokmashova, 2013).

2) In medical law concept of "motherhood" as we have already pointed out, is a woman's right to reproductive choice. In other contexts, this concept is not used. It is obvious that the right to reproductive choice as a man can possess. For example, the right to a deferred paternity. However, current Russian legislation does not contain any relevant legal norms.

3) The concept of "motherhood" is also used in labor law where it is interpreted as a definite- "urgent" state, the so-called "active motherhood". During the "active motherhood" includes pregnancy, childbirth, breastfeeding and baby care for a child under one and a half years.

It is important to note that the priority given by the legislator to protect women, in fact, does not mean that her rights are protected. There are many factors influence to the status of women in society - the economic situation, the profession, the availability of work - up to the system of value orientations in family life and motherhood (Trounova, 2004, p. 8).

There is a view that to ensure legal equality should abandon protectionist or special legislation. "Unique" and "feature" women are treated as a kind of hindrance. For specific legislation is believed to proponents of this position can be used, rather, to deny equal rights for women than for their achievements. Therefore advocates the need for gender-neutral legislation (Samoylova, 2010).

In connection with the numerous ethical and religious issues arising in connection with the use of laws of surrogacy in many countries, restrict using of this method. Carry and give birth to such couple - a noble goal, but both legally and ethically problematic (Sviridonova, 2006).

Islam and Christianity can be identified quite certain attitude towards the possibility of using assisted reproductive technologies for infertility treatment.

In accordance with Islamic theological and legal opinions childlessness or infertility (as well as the birth of a child and his subsequent education) is a test of God. Perceive this test with meekness and humility, trusting in the mercy and grace of the Most High, in charge that transcends human understanding - the lot of God-fearing people and steadfast in the faith. Childlessness - is a sign of consolation that comes, because grace Merciful Creator promised to those who can withstand the test without his despondency and despair. An example of this - the emergence of fertile offspring of Abraham and the parents of the Virgin Mary (Ayvar, 2006).

The underlying principle is to provide Sharia diverse human interests, its needs and to facilitate his life. On this basis, Islamic law is aimed at providing guarantees for the preservation of basic human fundamental values: religion, life, intellect, honor, and dignity and procreation property. These guidelines define the Islamic approach to the problem of infertility (Sergeyev, 2006).

If thorough medical examination will identify avoidable by treating the cause of infertility, in the opinion of Islamic theologians, it is necessary and permitted the use of various forms of treatment for this disease, do not violate the pristine, natural human nature (Dronova, 2007).

If traditional infertility treatments are ineffective, and taking into account the age and individual characteristics of the spouses, as well as the presence of authoritative medical evidence about the inability to use any other methods, it is permissible to use assisted reproductive technologies, including in vitro fertilization (Sergeyev, 2006). 
Using the method of the surrogate motherhood raises the problem of determining the true mother of a child that has spiritual and religious, ethical and legal aspects. In addition, lawyers noted the possible adverse effects of widespread use of this method: financially secure families bother to stop the problem of pregnancy and childbirth can have up to twelve children per year, as in a healthy woman's body produces monthly egg is ready to conceive, etc. (Sergeyev, 2006)

The Christian Church is opposed to surrogate motherhood. The church, recognizing the importance of procreation, does not consider it for the sole purpose of marriage. Defining marriage as "a sacrament of love", they see the ethical value sex spouses in full and mutual self-giving, where body and soul are united. Moreover, this unity is not limited to the reproduction of the human race (Balashov, 2005).

Opponents of surrogate motherhood is not without reason to fear the harmful practice of turning children into a kind of commodity, creating a situation where the rich will be able to hire women for bearing their descendants. Motherhood thus becomes contractual work, and the pursuit of material gain can prevail over common sense here and considerations for the use of the contracting parties (Basavina, 2007).

In addition, many feminists believe that this practice will contribute to the exploitation of women and religious leaders see it as immoral tendency undermines the sanctity of marriage and the family.

There are real concerns that some surrogate mothers may be quite traumatized need to pay became "his" in the first nine months of pregnancy and birth of the child, which establish a strong spiritual connection (even if at first the woman felt that she would be able to part with such a child without special experiences).

Supporters of the using of surrogate motherhood look at this problem quite differently. They point out that for the childless family because of the inability to conceive a wife or make child, this is the only way to get a child who is genetically native to both spouses and husband. They also note that such a procedure, which allows giving birth to a child desired, in fact not so very different from the adoption (Kirichenko, 2011).

According to them, this is not the commercialization of reproduction, and deeply humane act of love and cooperation. This act is related, of course, with potential risks for the surrogate mother, but she is able to evaluate them and can consciously take the risk. Thus, the decision on the conclusion of the contract was not going for it more risky than many other women opting for yourself is not quite safe activity (Ivaeyeva, 2008).

Supporters of surrogate motherhood do not consider it a form of exploitation of women; they argue that a woman who voluntarily chooses to become a surrogate mother, receives this role adequate financial compensation as well as the moral satisfaction brought by other people and society benefit (Kirillovih, 2012).

Relatively little attention in such situations is given to the child. It can inherit from a surrogate mother genetic defects (except when implanted in her uterus fertilized in vitro (in a test tube) from the egg of the woman herself, instead of that for gestation had to hire another). Some of these defects, unfortunately, cannot be detected by modern methods.

Develop a common concept of "motherhood", as well as the introduction of such legislation the rights of citizens (women and men) on motherhood and fatherhood, in our opinion, are designed to protect individuals from discrimination based on sex (Chreetinin, Gardanova, \& Koolakova, 2008).

From a medical point of view, surrogate motherhood is one of the most effective ways to overcome the inability to bear children. However, it is the most controversial in the legal and ethical method of assisted reproductive technology. In different states to address issues associated with the use of this method in different ways.

Despite widespread surrogate motherhood, according to a survey of 18 to $28 \%$ of the population (depending on age and region) consider this method unacceptable and immoral, and $24 \%$ do not have on this matter of opinion due to the fact that few are aware of the nature of the problem (Pestrikova, 2008).

Generally, modern reproductive technologies - this equation with several unknowns. On the one hand, reproductive technologies allow overcoming the problem of infertility, and to ignore them would be absurd. On the other hand, the development of modern biomedical technology is such leaps and bounds that society does not have time to understand, to some spiritual, moral and social impacts may result dissemination. Because today surrogacy as new reproductive technologies in general - is a tangle of legal, religious, moral and ethical issues.

Most disputes arise around the use of a surrogate (substitute) motherhood, the essence of which lies in the fact that the woman with the help of artificial insemination agrees to carry and give birth to a child for the couple, who cannot for health reasons have children.

Opponents of surrogate motherhood believe that it turns children into a kind of product, creating a situation in which the rich will be able to hire women for bearing their descendants. They also argue that motherhood 
becomes at the same timework contract, so the pursuit of profit can prevail over considerations here for the benefit of the contracting parties. In addition, many feminists think that this practice will contribute to the exploitation of women, and some church groups see it as dehumanizing, immoral tendency undermines the sanctity of marriage and the family (Tokmashova, 2013).

There are also concerns that some surrogate mothers may need to give traumatized "their" child after the establishment of the connection with it, which was created during the 9-month pregnancy and delivery (if the woman initially thought that it would be able to leave with the child without any experience).

First, the opponents of surrogate motherhood are a church that believes that its implementation entails a profound disregard for the emotional bond that's established between mother and child during pregnancy. In addition, representatives of the Church, recognizing the importance of procreation, do not consider it for the sole purpose of marriage. Defining marriage as "a sacrament of love", they see the ethical value sex spouses in full and mutual self-giving, where body and soul are united. Moreover, this unity is not limited to the reproduction of the human race.

The Orthodox Church, taking the idea of synergy, i. e. co-creation of God and man in the transformation of the world, however, rejects any claim to replace the last of the Creator of the universe. Therefore, if the husband is infertile, and medicine are not able to help him, the wife should take it for what it is, without trying in one way or another to find him a substitute.

Moral issues of surrogate motherhood cannot remain indifferent spiritual leaders. Jubilee Council of Bishops, held in Moscow in August 2000, clearly defines the attitude of the Orthodox Church to surrogate motherhood: "manipulations related to the donation of germ cells do violate the integrity of the person and the unique nature of marital relations, allowing of a third party.

"Surrogacy" that is, the bearing of a fertilized egg a woman who returns after delivery of the child "customers", unnatural and morally inadmissible even in those cases where they are on a commercial basis. This technique involves the destruction of deep emotional and spiritual intimacy is established between mother and baby during the pregnancy. "Surrogacy" hurts both the bearing woman, whose mother's feelings are trampled upon, and the child who may subsequently experience an identity crisis" (Pestrikova, 2008).

Somewhat differently to the problem of surrogate motherhood suits the Muslim religion. Since the countries professing Islam, polygamy is allowed and then the surrogate mother can be another wife of her husband.

The practice has been criticized substitute motherhood and for the opportunity to commercialization. It lies in the fact that this method can be used as a means of exploitation of women as paid incubators producing children for wealthy customers. There are a lot of facts. Recently in Moldova was exposed criminal organizations involved in smuggle children abroad. Mother "donors" in the period of pregnancy know where babies will be sent. In Hungary the criminal proceedings were instituted against the doctor-geneticist Endre Tseyzelya, who along with his partner, being in America, was also involved in a similar "business" (Voyevodin, 1997).

Prohibiting the use of surrogate motherhood for commercial purposes stated in the Brussels Declaration of the World Medical Association (1985). In addition, this method can be applied in the institutions of state and municipal health care system, and only in cases where the person who ordered for health reasons cannot independently carry and give birth to a child.

Reduce the risk of commercialization of surrogate motherhood may contribute to the fact that as a substitute mothers can act relatives infertile couples who will treat your child with genuine love. For example, in Australia in 1994 was filmed a number of limitations with the law on the use of surrogate motherhood, which allowed her sisters and cousins genetic parents become substitute mothers. In Russia, the first child appeared in 1991 in Kharkov, under the supervision of professors V. I. Grishchenko and F. V. Dahno. In this case, the mother gave birth to the child's own daughter, who had congenital absence of uterus (Svitnev, 2011).

Supporters of the use of surrogate mothers, of course, look at this practice quite differently. They point out that for the family, childless because of the inability to conceive a wife or make fruit, this is the only way to get a child who is genetically "their" for her husband. They also note that such a procedure, which allows giving birth to a child desired, in fact not so very different from adoption.

According to them, this is not the commercialization of reproduction, and deeply humane act of love and cooperation. This act is related, of course, with potential risks for the surrogate mother, but she is able to evaluate them and can consciously take the risk; Thus, the decision on the conclusion of the contract were not going for it more risky than many other women opting for yourself is not quite safe classes. 
Supporters of surrogate motherhood do not consider it a form of exploitation of women; they argue that a woman, who voluntarily chooses to become a surrogate mother, receives this role adequate financial compensation as well as the moral satisfaction brought by the public benefit (Pestrikova, 2008).

As noted by one of the surrogate mothers in northern California, "I cannot feed the hungry, I cannot stop the war, but I can slightly change the world by helping spouses to become a full-fledged family" (Shevchook, 2012).

The research conducted by Dr. Betsy H. Aigen, showed that more than $40 \%$ of the 200 respondents surrogate mothers at the conclusion of an Agreement for surrogate motherhood did not come from the material of interest, and, above all, wanted to help childless couples to find "their" child. In addition, as noted by the judge Sork (Australia), there are two arguments in favor of the service contracts of surrogate motherhood is not a contract for the sale of children (Afanasiev, 2012).

Firstly, the parties entering into a contract already agreed that the child will be given spouses customers (parents betrothed), and secondly, naming parents can establish a genetic relationship with the child and thus prove their parental rights to it. Of course, we cannot agree with these conclusions, but one must also consider that the application of surrogate motherhood may be used as the genetic material of the surrogate mother, and anonymous donors.

Foreign practice has considerable experience in the application of this institution, although it cannot characterize as unique. Now the issue of surrogacy has more relevance abroad.

The first judicial claim related to the dispute between the surrogate mother and the couple had taken place in the United States in 1988. The case, known as In re Baby M, was associated with a court decision on the transfer of the child of a surrogate mother who refused compensation for $\$ 10000$ and decided to keep the child. After this incident, the jurisprudence was not as unanimous in their decisions, despite the dominance of judicial precedent in the Anglo-Saxon law (Shevchook, 2012).

In some states, surrogacy is completely forbidden (e.g. France, Germany). Surrogacy is illegal in France, and the Supreme Court of Appeal (Cour de Cassation) ruled that it is contrary to the law on adoption and violates a provision not alienability human body. Crime is any attempt to carry out artificial insemination of a woman willing to give up their child after birth (the surrogate mother), or implanted her human embryo. The penalty shall be a doctor, but do not carry the intended parents or surrogate mother.

In other states banned only commercial surrogacy agreement and shall not be considered legal action under these agreements. These states are: Canada, Israel, United Kingdom, Victoria (Australia), New Hampshire and Virginia (USA).

Finally, some states limit the use of reproductive technologies in connection with surrogacy (Denmark, Norway, Sweden) (Grayce, 2005).

According to the doctors, in Russia there are no bank surrogate mothers. If a couple wants to have a baby and are willing to go through surrogacy, they are compelled to look for women who are ready to help them.

Differently put the matter in the United States. Base allows you to choose a donor, guided by specific criteria, such as ethnic origin, religion, eye and hair color, height, weight, location, etc. (Tyitlyanova, 2012)

You can also learn about the requirements for surrogate mothers. Here are 12 questions to help you choose the clinic or program. For example, the existence of the clinic, the number of pregnancies achieved, the number of physicians in the state, programs offered by the clinic, psychological and medical testing of surrogate mothers, and the existence of the trust account. You can also learn what to do if the surrogate mother will require additional funding, which passes testing surrogate mother, the emotional support of the donor and the recipient, the cost of services.

Relatively little has been said about the child in such situations. The child may inherit from surrogate mother genetic defects (except for a rather rare occasions when implanted in her uterus fertilized "in vitro" ovum from the very woman that instead of gestation had to hire another) (Stebleva, 2012).

Some of these defects, unfortunately, cannot be detected by modern methods. May also damage the fetus because of negligence of a surrogate mother-for example, if it is during pregnancy, or using drugs is not well fed. Equally important, but remain unanswered questions about the psychological adaptation of the child. If the child to explain (or he accidentally discovers) that it bore no mother, and another woman, not whether it will be for him a source of problems or painful experiences? In addition, if the child's contact with this woman will continue after his birth (it happens when the surrogate mother-a relative or close family man), how it can affect a child in the future? 
It is not surprising that there were so many issues a special committee of the American Society for Combating infertility expressed about surrogate motherhood serious doubts about the ethical nature that cannot be removed until sufficient data to assess the risks and possible benefits of the procedure discussed (Shevchook, 2012).

Due to these doubts, referred Society recommends the use of surrogate motherhood only in the order of the clinical experiment under the following conditions:

1) It is necessary to collect sufficient information on the psychological impact of the procedure on the surrogate mothers to use their couples and children born;

2) Particular attention should be paid to the spouse and the surrogate mother gave informed consent to the procedure, all the necessary information;

3) The father and the surrogate mother should be carefully checked for infectious diseases and genetic defects;

4) Payment for services professionals — doctors, lawyers, and others—-shall be limited to the usual fees for them; they should not receive a commission for the selection of participants and the organization of the entire procedure (Pestrikova, 2008).

Despite these recommendations, in some cases, surrogacy will undoubtedly be organized under less stringent conditions (and less professionally). Now it is obvious that for some women offering their services, as surrogate mothers are the main stimulus money and it can push them to provide false information about the health or life circumstances.

There are cases when infertile couples, looking for a suitable role for a woman who tried to persuade him to agree to it any of the relatives. On the other hand, unscrupulous or seriously enough relevant lawyers and doctors, sometimes so addicted to the prospect of good money on the selection of surrogate mothers, which is not able to act only in the interests of their clients. Yet, how can attest to hundreds of previously childless couple, the use of this method to overcome infertility invaluable (Stebleva, 2012).

Despite the presence of conflicting opinions about surrogate motherhood, a method will actively continue to develop. The main reason for this is that, despite the high cost and complexity to the ethical and legal side, it remains popular.

For many childless couples the birth of her child genetically, let another woman and bred, is more desirable than the adoption of a completely alien baby. Although the latter method of family planning is more humane and the only acceptable from the point of view of the church, one can hardly condemn unequivocally spouses who have decided to hire the services of a surrogate mother. The reasons pushing them to such a decision may be a lot as for surrogate mothers themselves. However, the greatest psychological stress while they are themselves, and get a lot of money not only spent on someone else's child health and strength, but also for the resulting moral injury that will stay with them for life (Tyitlyanova, 2012).

\section{Conclusion}

One cannot but agree with the I. F. Alexandrov that further development of family and civil law should follow the path of advance coordination and cooperation, joint gaps and are not yet regulated relations at the junction of the two branches of law, a joint resolution of emerging issues in a more global regulation of public relationship.

This area in the twenty-first century may be the area of human reproduction, which inter-sect the general theoretical issues, family law, civil, moral and legal questions of ethics and human rights, as well as other spheres of human activity. As of today, there is an urgent need for legal regulation of these relations.

The need for legislative resolve the issue of surrogate motherhood in Russia is also not in doubt. Based on the above, seems desirable to adopt a special law on reproductive activity, which would more clearly define the term and defines the concepts, establishing conditions for in vitro fertilization and embryo implantation, and orders the relationship between all the stakeholders. In this case, the main purpose of the law should be to achieve the degree of elaboration and detail, which would help to fully protect the child and ensure their rights.

\section{References}

Ayvar, L. K. (2006). Lawfully Assisted Reproductive Technologies: Surrogacy. Legal Consultant, 6-11.

Afanasiev, S. F. (2012). Civil Procedure Aspect Surrogate Motherhood. Russian justice, 65-68.

Balashov, O. N. (2005). In vitro Fertilization: What Orthodox People Think. Human, 78.

Basavina, P. A. (2007). The Problem of Determining the Status of Reproductive Rights. The problems of modern Russian law, 97-100. 
Chreetinin, D. F., Gardanova, J. R., \& Koolakova, E. V. (2008). Borderline mental disorders of women with infertility in the programs of "surrogate motherhood" in the limits of treatment by in vitro fertilization. Mental disorders in general medicine, 6-8.

Dronova, Y. A. (2007). What do You Need to Know about Surrogate Motherhood. Gorodets, 34.

Grayce, P. S. (2005). Ethical problems surrounding surrogate motherhood. The Yale-New Haven Teachers Institute, 254.

Ivaeyeva, E. A. (2008). Surrogate Motherhood: The Legal and Moral Measurement of the Problem. Medical Law, 12.

Kirillovih, A. A. (2012). The Reproduction of the Person in Legal Focus. Medical Law, 20-25.

Kirichenko, K. A. (2011). Models of Legal Regulation of the Relations Developing in the Implementation of Methods Assisted Reproduction: A Comparative Legal Analysis. Russian legal journal, 69.

Kozheourova, O. B. (2009). The Problems of Implementation of Subjective Rights of Parties of the Reproductive Relationship. Modern Law, 90-92.

Makeyeva, O. A. (2011). Family Law of Russian Federation: The Main Problems, Perspectives of Further Development: The Methodology of Teaching of Family Law. The Family and Housing Law, 12-14.

Pestrikova, A. A. (2008). The Surrogate Motherhood in Russian Law. Samara Humanitarian Academy, 180.

Pourge, A. R. (2012). The Problems of the Legal Regulation of Surrogate Motherhood in Russia. Eurasian Legal Journal, 132-135.

Samoylova, V. V. (2009). The Problems of Surrogate Motherhood in Russian Federation. Law and Education, $155-161$.

Samoylova, V. V. (2010). The Russian and Foreign Family Legislation about Application of Assisted Reproductive Technologies. The Family and Housing Law, 7-10.

Sviridonova, T. I. (2006). Civil Regulation of Surrogate Motherhood (p. 10). St. Pt.

Svitnev, K. N. (2011). Assisted Reproductive Technologies: Legal Collisions. The Legal Issues of healthcare, 52-61.

Sergeyev, Y. D. (2006). The Problems of Legal Regulation of the Application of the Assisted Reproductive Technologies' Methods. Medical Law, 9-20.

Stebleva, E. V. (2012). The Legal Nature of the Surrogate Motherhood's Contract. Russian Legal Academy's Bulletin, 35-38.

Shevchook, S. S. (2012). Some problems of legal regulation of application of artificial methods of reproduction. Lawyer, 18-25.

Tyitlyanova, E. V. (2012). The legal status of participants in the program of surrogate motherhood (pp. 91-95). Moscow: Modern Law, Novels in Russian Legislation.

Tokmashova, N. Y. (2013). On the question of need to obtain the consent by the genetic parents from a surrogate mother for the purchase of parental rights to the child (pp. 15-18). Moscow: The Family and Housing Law.

Trounova, L. K. (2004). Legal and practical aspects of surrogate motherhood. The Legal Consultant, 5-10.

Voyevodin, L. D. (1997). The Legal Status of Person (p. 304). Moscow: M-NORMA.

\section{Copyrights}

Copyright for this article is retained by the author(s), with first publication rights granted to the journal.

This is an open-access article distributed under the terms and conditions of the Creative Commons Attribution license (http://creativecommons.org/licenses/by/3.0/). 